\title{
Comparison of haematological indices between women of four ethnic groups and the effect of oral contraceptives
}

\author{
IF GODSLAND, MARY SEED, RUTH SIMPSON, G BROOM ${ }^{*}$ V WYNN \\ From the Alexander Simpson Laboratory for Metabolic Research and the * Department of Haematology, \\ St Mary's Hospital Medical School, London W2
}

SUMMARY Six-hundred-and-eighty-two women volunteers from four ethnic groups-Black, Indian, Oriental and White took part in a study to assess differences in haematological indices between the groups. This study was part of a broad investigation into the metabolic effects of oral contraceptives. The effect of the oral contraceptive (OC) on haematological indices was analysed but not found to be significant. The haemoglobin concentrations were lower than normal laboratory reference values for White subjects in $12.5 \%$ of Indian, $16.5 \%$ of Black and $4.3 \%$ of Oriental control groups respectively. All the White control group were within the normal range. These findings were considered in relation to age, weight, pregnancies, smoking, alcohol consumption, nutritional status, and disorders of haemoglobin synthesis.

A deficient iron intake accounted for the high incidence of low haemoglobin in the Indian group in whom low transferrin saturation and serum ferritin were observed.

With the possible exception of inherited disorders of haemoglobin synthesis, none of the factors we considered could account for the low haemoglobins found in the Black group. Separate reference values for haematological indices in different ethnic populations are considered.

In connection with an investigation into the metabolic effects of oral contraceptives in women of different ethnic groups, we became aware of a high proportion of low haemoglobin concentrations in our Black and Indian populations. If these results are taken as diagnostic for anaemia in Blacks and Indians, then we are confronted with a considerable health problem. However, it may be that the levels we observed are appropriate for healthy Black and Indian individuals.

The majority of laboratories in this country base their normal ranges on a predominantly White population. In investigating individuals from other ethnic groups such as the Black, Indian and Oriental populations now present in any large city in the UK, use of criteria based on White populations for assessing normality may be misleading.

Published studies of haematological differences between ethnic groups living in the same community are scarce. The most exhaustive studies have been between American Blacks and Whites. Analysis of data from two major nutritional surveys ${ }^{1-3}$ showed a

Accepted for publication 25 August 1982 mean haemoglobin $(\mathrm{Hb})$ level in Blacks $1 \mathrm{~g} / \mathrm{dl}$ less than in Whites. This difference was independent of age, economic level, nutritional status, and geographical area and has been confirmed in subsequent studies. ${ }^{4-6}$

The possible contribution to these findings of inherited defects in $\mathrm{Hb}$ structure or deficiencies in $\mathrm{Hb}$ synthesis does not appear to have been extensively explored. A defective $\mathrm{Hb}$ characteristically associated with Black populations is $\mathrm{HbS}$, which is present as a trait in $15 \%$ of Blacks but does not have any significant effect on haematological indices. However, non-fatal inherited diseases of $\mathrm{Hb}$ synthesis, classified under the thalassaemia syndromes, may be present in one-third of the Black populations, ${ }^{78}$ and may significantly affect haematological indices. ${ }^{9}$

Comparative studies between Indians and Whites are scarce. A high incidence of anaemia is believed to occur in Indian women as immigrants to the United Kingdom and the few studies that have been carried out suggest a nutritional origin for this anaemia. ${ }^{10}$ "1 Surveys both on the Indian sub-continent and in the UK, suggest a significant incidence of thalassaemia among Indian populations, ${ }^{2829}$ and this could 84 
contribute to differences in haematological indices between Indians and Whites.

Our study also included a group of Oriental subjects. Available evidence suggests no significant differences in the haematological indices between Orientals and Whites ${ }^{68}$ although inherited disorders of globin chain synthesis do appear to be widespread.

The data we have analysed were derived from an investigation into the effects of the $\mathrm{OC}$ in women of different ethnic groups. The OC has been shown to change significantly parameters likely to affect haematological indices, ${ }^{12} 14$ but studies demonstrating this have only involved White women. Therefore, in assessing the effects of the oral contraceptive in other ethnic groups, an evaluation of haematological differences is essential, and a comparison of haematological indices in OC users and non-users in each ethnic group is included in the following study.

We have considered observed haematological differences between different ethnic groups with regard to possible contributing or causative factors. Age, weight, pregnancies, smoking, alcohol intake, incidence of infection or infestation, disorders of haemoglobin synthesis, iron status and general nutrition and dietary history were analysed for each ethnic group. With regard to iron status, serum ferritin, iron and total iron binding capacity (TIBC) were measured on a sample from each group. Total protein; albumin, serum calcium, phosphate and alkaline phosphatase, as well as dietary information, are considered with reference to general nutrition.

\section{Subjects:and methods}

The majority of women in this study were volunteers responding to a printed circular. Women were grouped as Black, Indian, Oriental and White. To be included in a group, each subject had to have at least three grandparents belonging to that group. In the Black group, $50 \%$ were from the West Indies, $30 \%$ were from Africa and $20 \%$ were born in the UK of West Indian parents. In the Indian group, $35 \%$ were from India and Sri Lanka, 7\% from Pakistan and Bangladesh, $42 \%$ from East Africa and $11 \%$ from the West Indies. Orientals came from the Far East and South East Asia and Whites were predominantly from the UK. Women were further divided into control groups if they had not taken the oral contraceptive for at least three months prior to the study, and OC groups if they had been taking the OC for three months or more.

Subjects attended a day investigation unit, where a medical and dietary history was taken. Blood was taken between 0900 and $0930 \mathrm{~h}$, after a $12 \mathrm{~h}$ fast. To standardise the effect of posture on plasma volume dependent variables, ${ }^{15}$ subjects were semirecumbent for $30 \mathrm{~min}$ prior to blood sampling. Blood was obtained without stasis, from an in-dwelling venous cannula. Full blood counts were performed on a Coulter Counter, Model S, maintained within quality control limits using Coulter reference control $4 \mathrm{C}$ and an in-house QC preparation. The following indices were considered: $\mathrm{MCV}, \mathrm{RBC}, \mathrm{PCV}, \mathrm{Hb}, \mathrm{MCH}$, MCHC and white cell count (WBC). Erythrocyte sedimentation rate (ESR) was measured (Westergren) and Blacks were screened for sickle cell trait by haemoglobin electrophoresis. An SMA screen was carried out for each subject, and parameters considered in this study are serum total protein, albumin, calcium, phosphate and alkaline phosphatase, each by standard Technicon methods. Serum ferritin was measured by a specific radioimmunoassay (Beckton \& Dickinson, Product No 241130). Serum iron was measured by bathophenanthroline without deproteinisation (Boehringer, Mannheim, Product No 124222) and TIBC by magnesium carbonate precipitation (Boehringer, Mannheim, Product No 125806). Transferrin saturation was calculated by the serum iron expressed as a percentage of the TIBC.

Women were excluded from this study if they were already under treatment for any previously diagnosed disease. Women with ages outside the reproductive age range of $16-45$ yr were also excluded. To assess differences in weight between different ethnic groups, weights were expressed as a percentage of each individual's ideal body weight. ${ }^{16}$ Percentage ideal body weight (\% IBW) was taken as an expression of the height, weight, age relationship in each individual. Those with \% IBW of greater than $150 \%$ were excluded from the study. Subjects with MCV less than $74 \mathrm{fl}$ and RBC greater than $5.0 \times$ $10^{12} / 1$ were considered likely to have betathalassaemia trait and haemoglobin electrophoresis was carried out in these cases. Those with abnormally high $\mathrm{HbA}_{2}$ levels were excluded from the study. The numbers excluded are presented in Table 4 (see later). Final numbers in each group were: Black control 123, Black OC.142; Indian control 109, Indian OC 79; Oriental control 117, Oriental OC 59; White control 69, White OC 84.

STATISTICAL ANALYSIS

Analysis of the distribution of the data showed variations in the form of the frequency distributions for each parameter between different ethnic groups. Therefore, in testing for significant differences, nonparametric techniques were used throughout. The Mann-Whitney $U$ test was applied in testing for significant differences in a parameter between any two groups. In comparison between the four different ethnic groups a Kruskall-Wallis one way analysis of 
Table 1 Medians and ranges (in parentheses) for haematological indices, age and percentage ideal body weight and pregnancies per person for control and $O C$ groups in each ethnic group

\begin{tabular}{|c|c|c|c|c|c|c|c|c|}
\hline & \multicolumn{2}{|l|}{ Blacks } & \multicolumn{2}{|l|}{ Indians } & \multicolumn{2}{|l|}{ Orientals } & \multicolumn{2}{|l|}{ Whites } \\
\hline & Controls & $O C$ & Controls & $O C$ & Controls & $O C$ & Controls & $O C$ \\
\hline $\begin{array}{l}\text { No of cases } \\
\mathrm{Hb}(\mathrm{g} / \mathrm{dl})\end{array}$ & $\begin{array}{l}123 \\
12 \cdot 46 \\
(8 \cdot 9-14 \cdot 5)\end{array}$ & $\begin{array}{l}142 \\
12 \cdot 52 \\
(10 \cdot 2-14 \cdot 2)\end{array}$ & $\begin{array}{l}109 \\
12 \cdot 36 \\
(8 \cdot 7-14 \cdot 9)\end{array}$ & $\begin{array}{l}79 \\
12 \cdot 58 \\
(9 \cdot 8-14 \cdot 1)\end{array}$ & $\begin{array}{l}117 \\
12 \cdot 50 \\
(10 \cdot 5-14 \cdot 9)\end{array}$ & $\begin{array}{l}59 \\
12 \cdot 78 \\
(10 \cdot 8-15 \cdot 0)\end{array}$ & $\begin{array}{l}69 \\
12 \cdot 93 \\
(11 \cdot 3-15 \cdot 0)\end{array}$ & $\begin{array}{l}84 \\
12 \cdot 78 \\
(11 \cdot 2-14 \cdot 9)\end{array}$ \\
\hline PCV & \multicolumn{2}{|c|}{${ }_{\mathrm{NS}}^{(0 \cdot 300-0 \cdot 433)}(0 \cdot 296-0 \cdot 434)$} & $\begin{array}{l}0 \cdot 369 \\
(0 \cdot 289-0 \cdot 436\end{array}$ & NS $0 \cdot 376$ & \multicolumn{2}{|c|}{$(0 \cdot 310-0 \cdot 440)+(0 \cdot 299-0 \cdot 501)$} & \multicolumn{2}{|c|}{$\begin{array}{c}0.383 \\
(0.335-0.443) \\
\text { NS }\end{array} \stackrel{0.377}{(0.320-0.433)}$} \\
\hline $\begin{array}{l}\mathrm{RBC} \\
\left(\times 10^{12} / 1\right)\end{array}$ & \multicolumn{2}{|c|}{$\begin{array}{cc}4 \cdot 333 & 4 \cdot 350 \\
(3 \cdot 31-5 \cdot 67) & (3 \cdot 32-5 \cdot 3\end{array}$} & \multicolumn{2}{|c|}{$\begin{array}{ccc}4 \cdot 320 & 4 \cdot 390 \\
(3 \cdot 39-5 \cdot 04) & (3 \cdot 77-5 \cdot 13)\end{array}$} & $\begin{array}{l}4 \cdot 242 \\
(3 \cdot 60-5 \cdot 10)\end{array}$ & $\mathrm{NS}^{(3 \cdot 56-5 \cdot 01)}$ & \multicolumn{2}{|c|}{$\begin{array}{cc}4 \cdot 277 & 4 \cdot 190 \\
(3 \cdot 89-5 \cdot 25) & (3 \cdot 59-5 \cdot 15)\end{array}$} \\
\hline $\begin{array}{l}\text { MCV } \\
\text { (f) }\end{array}$ & $\begin{array}{l}86 \cdot 3 \\
(65-100)\end{array}$ & $\begin{array}{c}86 \cdot 9 \\
(73-101)\end{array}$ & $\begin{array}{l}85 \cdot 3 \\
(69-99)\end{array}$ & $\begin{array}{l}85 \cdot 7 \\
(69-97)\end{array}$ & $\begin{array}{l}88 \cdot 7 \\
(75-101)\end{array}$ & $\begin{array}{l}89 \cdot 3 \\
(81-96)\end{array}$ & $\begin{array}{l}89 \cdot 1 \\
(77-99)\end{array}$ & NS ${ }^{(81-101)}$ \\
\hline $\begin{array}{l}\mathrm{MCH} \\
(\mathrm{pg})\end{array}$ & $\begin{array}{l}28 \cdot 74 \\
(19 \cdot 1-39 \cdot 9)\end{array}$ & NS & $\begin{array}{l}28 \cdot 70 \\
(20 \cdot 8-32 \cdot 7)\end{array}$ & $\begin{array}{l}28 \cdot 95 \\
(20 \cdot 2-32 \cdot 4)\end{array}$ & $\begin{array}{l}29 \cdot 61 \\
(24 \cdot 9-33 \cdot 5)\end{array}$ & $\begin{array}{l}30 \cdot 12 \\
(26 \cdot 0-32 \cdot 8)\end{array}$ & $\begin{array}{c}30 \cdot 14 \\
(25 \cdot 1-33 \cdot 2)\end{array}$ & NS ${ }^{30 \cdot 37}$ \\
\hline $\begin{array}{l}\mathrm{MCHC} \\
(\mathrm{g} / \mathrm{dl})\end{array}$ & $\begin{array}{l}33 \cdot 06 \\
(29 \cdot 4-35 \cdot 7)\end{array}$ & $\begin{array}{l}33 \cdot 01 \\
\text { NS }\end{array}$ & $\begin{array}{l}33 \cdot 24 \\
(28 \cdot 0-37 \cdot 7)\end{array}$ & $\begin{array}{l}33 \cdot 43 \\
\text { NS }\end{array}$ & $\begin{array}{l}33 \cdot 33 \\
(30 \cdot 4-43 \cdot 2)\end{array}$ & $\begin{array}{l}33 \cdot 50 \\
\text { NS }\end{array}$ & $\begin{array}{l}33 \cdot 68 \\
(32 \cdot 4-36 \cdot 0)\end{array}$ & NS ${ }^{(31 \cdot 7-35 \cdot 9)}$ \\
\hline $\begin{array}{l}\text { WBC } \\
\left(\times 10^{9} / 1\right)\end{array}$ & $\begin{array}{c}5 \cdot 18 \\
(2 \cdot 5-9 \cdot 8)\end{array}$ & NS $\begin{array}{c}5 \cdot 38 \\
(2 \cdot 8-10 \cdot 9)\end{array}$ & $\begin{array}{l}6 \cdot 12 \\
(2 \cdot 9-11 \cdot 3)\end{array}$ & $\mathrm{NS}^{(3 \cdot 3-9 \cdot 9)}$ & $\begin{array}{l}5 \cdot 63 \\
(2 \cdot 5-10 \cdot 0)\end{array}$ & $\begin{array}{l}6 \cdot 25 \\
(3 \cdot 9-11 \cdot 4)\end{array}$ & $\begin{array}{l}6 \cdot 18 \\
(3 \cdot 3-9 \cdot 8)\end{array}$ & $N S^{(3 \cdot 5-13 \cdot 3)}$ \\
\hline $\begin{array}{l}\mathrm{ESR} \\
(\mathrm{mm} / \mathrm{h})\end{array}$ & $\begin{array}{c}10 \cdot 5 \\
(2-68)\end{array}$ & NS & $\begin{array}{l}11 \cdot 6 \\
(2-95)\end{array}$ & $\mathrm{NS}^{(3-45)}$ & $\begin{array}{l}12 \cdot 1 \\
(1-64)\end{array}$ & vS $^{11 \cdot 9}$ & $\begin{array}{c}13 \cdot 5 \\
(2-40)\end{array}$ & NS $\begin{array}{c}9 \cdot 7 \\
(1-40)\end{array}$ \\
\hline Age (yr) & $\begin{array}{l}26 \cdot 0 \\
(17-45)\end{array}$ & NS $\begin{array}{c}24 \cdot 9 \\
(17-42)\end{array}$ & $\begin{array}{l}26 \cdot 2 \\
(17-45)\end{array}$ & $\begin{array}{l}26 \cdot 2 \\
(19-42)\end{array}$ & $\begin{array}{l}26 \cdot 3 \\
(19-45)\end{array}$ & $\begin{array}{l}25 \cdot 9 \\
(18-34)\end{array}$ & $\begin{array}{l}26 \cdot 8 \\
(16-45)\end{array}$ & NS $\begin{array}{c}27 \cdot 9 \\
(16-44)\end{array}$ \\
\hline$\%$ IBW & $\begin{array}{l}105 \cdot 3 \\
(75-149)\end{array}$ & $\begin{array}{l}104 \cdot 9 \\
\text { NS }\end{array}$ & $\begin{array}{l}93 \cdot 4 \\
(66-146)\end{array}$ & $\begin{array}{l}98 \cdot 3 \\
(69-147)\end{array}$ & $\begin{array}{l}89 \cdot 4 \\
(74-133)\end{array}$ & $\begin{array}{l}90 \cdot 3 \\
(71-130)\end{array}$ & $\begin{array}{l}102 \cdot 3 \\
(65-147)\end{array}$ & $\begin{array}{l}102 \cdot 5 \\
\text { NS }\end{array}$ \\
\hline $\begin{array}{l}\text { No of } \\
\text { pregnancies }\end{array}$ & $\begin{array}{r}0.5 \\
(0-8)\end{array}$ & $N S^{(0-14)}$ & $\begin{array}{c}0 \cdot 2 \\
(0-8)\end{array}$ & $\begin{array}{c}0 \cdot 5 \\
(0-5)\end{array}$ & $\begin{array}{c}0 \cdot 1 \\
(0-6)\end{array}$ & $\begin{array}{c}0 \cdot 3 \\
(0-4)\end{array}$ & $\begin{array}{c}0 \cdot 3 \\
(0-4)\end{array}$ & $\mathrm{NS}^{(0-6)}$ \\
\hline
\end{tabular}

Significant differences between control and OC groups shown as: ${ }^{*} \mathrm{p}<0.05 ;{ }^{* *} \mathrm{p}<0.01$; NS $=$ not significant.

variance was applied and a significant result followed by tests between each pair of races.

\section{Results}

Within the range of median ages encountered in this study, a woman is considered to be anaemic if a haemoglobin less than or equal to $12 \cdot 0 \mathrm{~g} / \mathrm{dl}$ is found. ${ }^{17}$ The standardisation of posture used in this study would be expected to result in a $7 \%$ lowering of mean haemoglobin concentrations. We have confirmed this under the conditions of the present study. Blood for full blood counts was taken from 22 volunteers immediately on arrival and subsequently after $30 \mathrm{~min}$ in a semirecumbent position. A reduction of $7.8 \%$ was found in each of the plasma volume dependent variables: Hb RBC and PCV. Therefore, in this study we have considered a woman to be anaemic with a haemoglobin of less than or equal to $11 \cdot 2 \mathrm{~g} / \mathrm{dl}$.

Since half of our subjects were OC users, it was necessary to determine whether the OC was having an effect on the haematological parameters under investigation. Medians, total ranges and numbers for each index and age, \% IBW and average number of pregnancies per woman in control and $O C$ groups are presented in Table 1. Also included is the significance of the difference between control OC groups for each parameter.

Numbers and percentages of women with low $\mathrm{Hb} \xi$ in each control and $\mathrm{OC}$ group are presented in Table $\frac{\mathrm{S}}{5}$ 2 . Incidence of low values in the control group as $\square$ compared with the OC is $3 \%$ more for the Blacks, $6.4 \%$ more for the Indians, and $2.6 \%$ more for the $N$ Orientals. In the White groups, only one anaemic individual was found and she was in the OC group.

In considering haematological differences between $N$ the different ethnic groups it is immediately apparent $\underset{T}{T}$

Table 2 Numbers and percentages of individuals in control and $O C$ groups in each ethnic group with $\mathrm{Hb} \leqslant 11 \cdot 2 \mathrm{~g} / \mathrm{dl}$

\begin{tabular}{lllll}
\hline & Blacks & Indians & Orientals & Whites \\
\hline Controls & 15 & 18 & 5 & 0 \\
OC & $12 \cdot 2 \%$ & $16.5 \%$ & $4 \cdot 3 \%$ & $0 \cdot 0 \%$ \\
& 13 & 8 & 1 & 1 \\
& $9 \cdot 2 \%$ & $10 \cdot 1 \%$ & $1 \cdot 7 \%$ & $1 \cdot 2 \%$ \\
\hline
\end{tabular}


Table 3 Significant differences between ethnic groups for haematological indices, age, \% IBW and pregnancies

\begin{tabular}{|c|c|c|c|c|c|c|c|}
\hline & $\begin{array}{l}\text { Overall } \\
\text { Kruskall- } \\
\text { Wallis test }\end{array}$ & $\begin{array}{l}\text { Black v } \\
\text { Indian }\end{array}$ & $\begin{array}{l}\text { Black v } \\
\text { Oriental }\end{array}$ & $\begin{array}{l}\text { Black v } \\
\text { White }\end{array}$ & $\begin{array}{l}\text { Indian } v \\
\text { Oriental }\end{array}$ & $\begin{array}{l}\text { Indian } v \\
\text { White }\end{array}$ & $\begin{array}{l}\text { Oriental v } \\
\text { White }\end{array}$ \\
\hline $\begin{array}{l}\mathrm{Hb} \\
\text { PCV } \\
\text { RBC }\end{array}$ & $\begin{array}{l}* * * \\
* * \\
\text { NS }\end{array}$ & $\begin{array}{l}\text { NS } \\
\text { NS }\end{array}$ & $\begin{array}{l}\text { NS } \\
\text { NS }\end{array}$ & $\begin{array}{ll}* * * & \downarrow \\
* & \downarrow\end{array}$ & * $\quad \downarrow$ & $\begin{array}{ll}* * * & \downarrow \\
* * * & \downarrow\end{array}$ & N* \\
\hline $\begin{array}{l}\mathrm{MCV} \\
\mathrm{MCH}\end{array}$ & $* * *$ & NS & $* * * \quad \downarrow$ & $\begin{array}{ll}* * & \downarrow \\
* * * & \downarrow\end{array}$ & $\begin{array}{ll}* * * & \downarrow \\
* * * & \downarrow\end{array}$ & $\begin{array}{ll}* * * & \downarrow \\
* * * & \downarrow\end{array}$ & ${ }_{*}^{N S} \downarrow$ \\
\hline $\mathrm{MCHC}$ & $* * *$ & NS & $* \quad \downarrow$ & $* * *$ & NS & $* * \quad \downarrow$ & $* *$ \\
\hline $\begin{array}{l}\text { WBC } \\
\text { ESR } \\
\text { Age }\end{array}$ & $\begin{array}{l}* * * \\
\text { NS } \\
\text { NS }\end{array}$ & $* * * \quad \downarrow$ & NS & $* * * \quad \downarrow$ & ${ }^{* *} \quad \uparrow$ & NS & $* *$ \\
\hline $\begin{array}{l}\% \text { IBW } \\
\text { Pregnancies }\end{array}$ & $* * *$ & $\begin{array}{ll}* * * & \uparrow\end{array}$ & $\begin{array}{ll}* * * & \uparrow \\
* * * & \uparrow\end{array}$ & ${ }_{*}^{\text {NS }} \uparrow$ & $\begin{array}{ll}* & \uparrow\end{array}$ & $\begin{array}{l}* * * \\
\text { NS }\end{array}$ & $\begin{array}{l}* * * \\
* *\end{array}$ \\
\hline
\end{tabular}

$* p<0 \cdot 05$.

$\begin{array}{rl}* * * & \mathrm{p}<0.01 \\ \mathrm{*} & <0.001\end{array}$

NS $=$ not significant.

Arrows indicate direction of the difference-for example, Black $v$ White $\mathrm{Hb}^{* * *} \quad \downarrow=$ Black median Hb is lower than White median Hb.

Table 4 Percentage of smokers, alcohol users and vegetarians, and subjects with confirmed beta-thalassaemia and sickle cell trait

\begin{tabular}{|c|c|c|c|c|}
\hline & Blacks & Indians & Orientals & Whites \\
\hline $\begin{array}{l}\text { Smokers } \\
\text { Alcohol users } \\
\text { Vegetarians } \\
\text { Beta-thalassaemia trait } \\
\text { Sickle cell trait }\end{array}$ & $\begin{array}{r}25 \cdot 7 \\
74 \cdot 6 \\
0 \cdot 7 \\
0 \cdot 8 \\
15 \cdot 0\end{array}$ & $\begin{array}{r}19 \cdot 0 \\
46 \cdot 4 \\
22 \cdot 0 \\
3 \cdot 2\end{array}$ & $\begin{array}{r}14 \cdot 7 \\
40 \cdot 0 \\
1 \cdot 6 \\
1 \cdot 7\end{array}$ & $\begin{array}{r}37 \cdot 2 \\
75 \cdot 0 \\
2 \cdot 0 \\
0 \cdot 7\end{array}$ \\
\hline
\end{tabular}

from Table 2 that low $\mathrm{Hb}$ concentrations are 7-18 times more prevalent among the Blacks and Indians than among Orientals and Whites. This difference is further emphasised when the haematological indices are compared between the four ethnic control groups from Table 1. Significance of the differences between the different ethnic groups are presented in Table 3. Blacks, Indians and Orientals all have significantly lower $\mathrm{Hb}$ concentrations than Whites.

In Table 4, the percentage of smokers, alcohol users, and vegetarians in each ethnic group is presented; also included are the percentages of those with confirmed beta-thalassaemia trait and sickle cell trait. Compared with the White group, the incidence of smoking in the other three groups was substantially reduced. Three quarters of Blacks and Whites took alcohol regularly. Vegetarianism was only a significant factor among the Indians of whom almost a quarter took no meat. Medians, total ranges, and numbers of cases considered in assessing the serum indicators of nutrition as shown in Table 5, and significant differences between the different groups are given in Table 6 . The lowest serum ferritin, iron and transferrin saturation, and highest TIBC were observed in the Indian group.

The percentage of individuals in each group with low serum ferritin, iron and transferrin saturation are also presented in Table 5. Serum ferritin was considered to be abnormal at a value of $\leqslant 12.0 \mathrm{ng} / 1,{ }^{18}$ serum iron at $\leqslant 7 \mu \mathrm{mol} / \mathrm{l}^{19}$ and transferrin saturation at $\leqslant 15 \% .^{20}$ The Indian groups contained substantially more individuals in these categories than any of the other groups.

Table 5 Medians, ranges and number of cases for serum indicators of nutrition: also percentage of individuals in each group with low serum ferritin, iron and transferrin saturation

\begin{tabular}{|c|c|c|c|c|}
\hline & Blacks & Indians & Orientals & Whites \\
\hline $\begin{array}{l}\text { Calcium } \\
(\mathrm{mmol} / \mathrm{l})\end{array}$ & $\begin{array}{l}2 \cdot 235 \\
(1 \cdot 98-2 \cdot 51) \\
102\end{array}$ & $\begin{array}{l}2 \cdot 215 \\
(1 \cdot 94-2 \cdot 54) \\
70\end{array}$ & $\begin{array}{l}2 \cdot 180 \\
(2 \cdot 03-2 \cdot 41) \\
36\end{array}$ & $\begin{array}{l}2 \cdot 232 \\
(2 \cdot 03-2 \cdot 45) \\
70\end{array}$ \\
\hline $\begin{array}{l}\text { Albumin } \\
(\mathrm{g} / \mathrm{l})\end{array}$ & $\begin{array}{l}41 \cdot 2 \\
(35-49) \\
109\end{array}$ & $\begin{array}{l}41 \cdot 2 \\
(34-48) \\
71\end{array}$ & $\begin{array}{l}41 \cdot 9 \\
(38-46) \\
37\end{array}$ & $\begin{array}{l}42 \cdot 5 \\
(36-52) \\
71\end{array}$ \\
\hline $\begin{array}{l}\text { Globulin } \\
(\mathrm{g} / \mathrm{l})\end{array}$ & $\begin{array}{l}27 \cdot 3 \\
(18-43) \\
108\end{array}$ & $\begin{array}{l}26 \cdot 0 \\
(20-38) \\
71\end{array}$ & $\begin{array}{l}26 \cdot 5 \\
(19-34) \\
36\end{array}$ & $\begin{array}{l}23 \cdot 6 \\
(15-33) \\
71\end{array}$ \\
\hline $\begin{array}{l}\text { Phosphate } \\
\text { (mmol/l) }\end{array}$ & $\begin{array}{l}1 \cdot 162 \\
(0 \cdot 83-1 \cdot 52) \\
98\end{array}$ & $\begin{array}{l}1 \cdot 153 \\
(0 \cdot 77-1 \cdot 41) \\
71\end{array}$ & $\begin{array}{l}1 \cdot 135 \\
(0 \cdot 29-1 \cdot 54) \\
36\end{array}$ & $\begin{array}{l}1 \cdot 143 \\
(0 \cdot 72-1 \cdot 72) \\
69\end{array}$ \\
\hline $\begin{array}{l}\text { Alkaline } \\
\text { phosphatase } \\
\text { (U/l) } \\
\text { Ferritin } \\
\text { (ng/l) }\end{array}$ & $\begin{array}{l}53 \cdot 5 \\
(26-163) \\
106 \\
24 \cdot 0 \\
(2-148) \\
55\end{array}$ & $\begin{array}{l}53 \cdot 8 \\
(17-142) \\
72 \\
12 \cdot 2 \\
(1-133) \\
58\end{array}$ & $\begin{array}{l}48 \cdot 3 \\
(25-115) \\
37 \\
28 \cdot 5 \\
(1-136) \\
38\end{array}$ & $\begin{array}{l}56 \cdot 6 \\
(21-140) \\
71 \\
17 \cdot 5 \\
(8-57) \\
42\end{array}$ \\
\hline $\begin{array}{l}\text { Iron } \\
(\mu \mathrm{mol} / \mathrm{l})\end{array}$ & $\begin{array}{c}15 \cdot 45 \\
(5 \cdot 2-29 \cdot 8) \\
40\end{array}$ & $\begin{array}{l}13 \cdot 18 \\
(1 \cdot 3-27 \cdot 0)\end{array}$ & $\begin{array}{l}15 \cdot 60 \\
(6 \cdot 3-29 \cdot 1)\end{array}$ & $\begin{array}{l}14 \cdot 35 \\
(4 \cdot 2-26 \cdot 7)\end{array}$ \\
\hline $\begin{array}{l}\text { TIBC } \\
(\mu \mathrm{mol} / \mathrm{l})\end{array}$ & $\begin{array}{l}40 \\
53 \cdot 35 \\
(28 \cdot 4-76 \cdot 5) \\
40\end{array}$ & $\begin{array}{l}53 \\
63 \cdot 70 \\
(30 \cdot 8-96 \cdot 4) \\
53\end{array}$ & $\begin{array}{l}40 \\
50 \cdot 95 \\
(35 \cdot 4-82 \cdot 0) \\
40\end{array}$ & $\begin{array}{l}40 \\
53 \cdot 55 \\
(36 \cdot 5-81 \cdot 8)\end{array}$ \\
\hline \multirow{4}{*}{$\begin{array}{l}\text { Transferrin } \\
\text { saturation } \\
\text { Ferritin } \\
(\leqslant 12 \cdot 0 \mathrm{ng} / \mathbf{l}) \\
\text { Iron } \\
(\leqslant 7 \mu \mathrm{mol} / \mathrm{l}) \\
\text { Transferrin } \\
\text { saturation } \\
(\leqslant 15 \cdot 0 \%)\end{array}$} & $\begin{array}{l}27 \cdot 91 \\
(7 \cdot 5-94 \cdot 7)\end{array}$ & $\begin{array}{l}20 \cdot 50 \\
(1 \cdot 7-59 \cdot 5)\end{array}$ & $\begin{array}{l}29 \cdot 40 \\
(10 \cdot 3-58 \cdot 2)\end{array}$ & $\begin{array}{l}25 \cdot 88 \\
(7 \cdot 6-57 \cdot 7)\end{array}$ \\
\hline & $29 \cdot 1$ & $51 \cdot 7$ & $33 \cdot 3$ & $26 \cdot 2$ \\
\hline & $7 \cdot 5$ & $17 \cdot 0$ & $7 \cdot 5$ & $7 \cdot 5$ \\
\hline & $10 \cdot 0$ & $30 \cdot 2$ & $10 \cdot 0$ & $15 \cdot 0$ \\
\hline
\end{tabular}


Table 6 Significances between ethnic groups nutritional indicators

\begin{tabular}{|c|c|c|c|c|c|c|c|}
\hline & $\begin{array}{l}\text { Overall } \\
\text { Kruskall- } \\
\text { Wallis test }\end{array}$ & $\begin{array}{l}\text { Black v } \\
\text { Indian }\end{array}$ & $\begin{array}{l}\text { Black v } \\
\text { Oriental }\end{array}$ & $\begin{array}{l}\text { Black v } \\
\text { White }\end{array}$ & $\begin{array}{l}\text { Indian } v \\
\text { Oriental }\end{array}$ & $\begin{array}{l}\text { Indian v } \\
\text { White }\end{array}$ & $\begin{array}{l}\text { Oriental } v \\
\text { White }\end{array}$ \\
\hline \multirow{8}{*}{$\begin{array}{l}\text { Calcium } \\
\text { Albumin } \\
\text { Globulin } \\
\text { Phosphate } \\
\text { Alkaline } \\
\text { phosphatase } \\
\text { Ferritin } \\
\text { Iron } \\
\text { TIBC } \\
\text { Transferrin } \\
\text { saturation }\end{array}$} & NS & & & & & & \\
\hline & $* *$ & NS & NS & ${ }^{* *} \quad \downarrow$ & NS & ${ }^{* *} \quad \downarrow$ & NS \\
\hline & $\begin{array}{l}* * * \\
\text { NS }\end{array}$ & ${ }^{*} \uparrow \uparrow$ & NS & $* * * \uparrow$ & NS & $* * * \quad \uparrow$ & ${ }^{* * *} \quad \uparrow$ \\
\hline & NS & & & & & & \\
\hline & 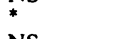 & ${ }^{* *} \quad \uparrow$ & NS & NS & $*$ & NS & NS \\
\hline & NS & & & & & & \\
\hline & $* * *$ & $* * \quad \downarrow$ & NS & NS & $* * * \quad \uparrow$ & ${ }^{* *} \quad \uparrow$ & NS \\
\hline & $* * *$ & $* * * \quad \uparrow$ & NS & NS & ${ }^{* * *} \quad \downarrow$ & $*$ & NS \\
\hline
\end{tabular}

* $p<0.05$.

$* * \mathrm{p}<0.01$.

$* * * \mathrm{p}<0.001$

NS = not significant.

Arrows indicate direction of the difference-for example, Indian $v$ Oriental transferrin saturation ${ }^{* * *} \quad \downarrow=$ Indian median transferrin saturation is lower than Oriental median transferrin saturation.

\section{Discussion}

Some differences in haematological indices might be expected in groups of control subjects and OC users on the basis of reports of raised serum iron and TIBC, reduced menstrual blood loss; folate deficiency and reduced erythropoiesis associated with $\mathrm{OC}$ use.

Incidence of folate deficiency, as indicated by an MCV greater than $99 \mathrm{fl}$, was no higher in our OC groups than in our control groups. In our Black, Indian and Oriental groups, higher $\mathrm{Hb}$ and $\mathrm{MCV}$ levels were found in OC users, as seen in the medians for each group. The analysis of the numbers of individuals with low $\mathrm{Hb}$ from control and $\mathrm{OC}$ groups shown in Table 2 supported this. These results suggest that the effects of the OC might be beneficial in raising haematological indices. However, this effect was only statistically significant between the $\mathrm{Hb}$ levels in Oriental control and $\mathrm{OC}$ groups. The lack of a significant effect of $O C$ use is particularly striking in the Black and Indian groups; although the OC reduces menstrual loss, there was no significant change in the already low $\mathrm{Hb}$ and MCV levels in these groups. Our findings agree with a study by Prema ${ }^{21}$ carried out in India in which the haematological effects of the $O C$ and intrauterine device (IUD) were compared for patients attending a family planning clinic. No difference was found in either mean $\mathrm{Hb}$ or MCV levels between OC and IUD users.

The White controls had significantly higher $\mathrm{Hb}$ levels than the OC group, the only parameter associated with this difference was the number of pregnancies, but no correlation was found between this and $\mathrm{Hb}$ or MCV levels.

In the comparison of haematological data between the different ethnic groups, the most striking finding was the low $\mathrm{Hb}$ and MCV found in the Black and
Indian groups. However, reference values derived from White populations may be inappropriate for our Black and Indian populations, where reference values may be lower as appears to be the case for $\overrightarrow{0}$ American Blacks. This will only be so if the observed $\underset{\omega}{\infty}$ levels cannot be accounted for by any factor contributing to their incidence in one ethnic group rather than another. Such factors are age, weight, pregnancies, smoking, alcohol intake, nutritional status and inherited disorders of haemoglobin synthesis.

The effect of age on MCV is clearly demonstrated in men ${ }^{22}$ and may be so for women on $\mathrm{OC}^{23} \mathrm{~A}$ weak positive correlation between age and $\mathrm{MCV}$ was found in our Black control and Mongolian control and OC groups, but there were no significant correlations in any other groups. There were no significant differences between the age distributions of the different ethnic groups.

The possible contribution of body mass to haematological differences between the races was $ᄋ$ difficult to assess. Percentage IBW was analysed to $D$ give an indication of the relation between weight, height and age. The Blacks in our study had the highest body mass for their age and the Orientals the lowest. Regression analysis showed that any effect of $\% \mathrm{HBW}$ on $\mathrm{Hb}$ and $\mathrm{MCV}$ was negligible.

Women in each ethnic group had a significantly different number of pregnancies from those in each of 0 the other groups. The number of pregnancies for $\mathbb{D}$ women in this study ranged from $0-14$, but possible ? effects on haematological indices associated with this $T$ parameter were discounted by the complete lack of correlation found between number of pregnancies and $\mathrm{Hb}$ and $\mathrm{MCV}$.

There was a marked difference in smoking habits between women of different ethnic groups. Smoking 
has been shown to raise both $\mathrm{Hb}$ and $\mathrm{MCV}^{23}$ and could thus account for the comparatively high levels of both these indices found in our White group. We therefore divided those women for whom information on smoking habits had been obtained, into smoking and non-smoking groups. Both median $\mathrm{Hb}$ and $\mathrm{MCV}$ levels were consistently higher in the smokers of each ethnic group. Comparisons between the non-smokers, $\mathrm{Hb}$ and MCV levels for each ethnic group resulted in there no longer being a significant difference between the Orientals and Whites. Incidence of smoking failed to account for the differences observed between the Whites, and Black and Indian groups.

Regular alcohol intake occurred in all groups. Liver function tests showed no evidence of alcohol abuse in any of our subjects. However, even moderate alcohol consumption has been known to raise the MCV. ${ }^{22}$ Three quarters of both Blacks and Whites in our study took alcohol, yet the Black median MCV was low relative to that of the Whites. The small effect of alcohol on the MCV that has been demonstrated would not account for any ethnic differences observed.

Chronic infection is known to be associated with anaemia and intestinal infestation has been shown to be an aggravating factor in the high incidence of anaemia found in the Indian subcontinent. ${ }^{24}$ These conditions would be expected to be accompanied by an increased incidence of eosinophilia, raised WBC and ESR which were not found. The Black WBC was significantly lower than in the other three groups in agreement with other studies. ${ }^{25}$

Disorders of haemoglobin synthesis vary in their distribution among different ethnic groups. Betathalassaemia has the greatest effect on haematological indices and subjects with this trait were excluded from this study. The alpha-thalassaemias are less severe in their haematological effects, but can still significantly affect haematological indices. ${ }^{9}$ The double gene deletion, alpha-thalassaemia 1 , has been reported in $5.6 \%$ of Black Americans, ${ }^{7}$ whereas single gene deletion alpha-thalassaemia 2, may appear in up to $27.5 \%,{ }^{8}$ thus the thalassaemias could contribute substantially to the haematological differences between Black and White populations. However surveys in Black Americans did not correlate the incidence of either alpha 1 or 2 thalassaemia with haematological indices. Alpha-thalassaemia in Indians appears to have a genetic basis similar to that found in Blacks $^{29}$ and incidences of $1-4 \%$ are reported. ${ }^{26}$ Among Orientals, studies in Thailand have demonstrated frequencies for alpha-thalassaemia 1 of up to $12 \cdot 2 \%$ and for alpha-thalassaemia 2 of up to $17 \cdot 4 \% .27$ The alpha-thalassaemias also appear to be widespread in other parts of South East Asia and
China. As alpha-thalassaemia alters haematological indices, we would expect a proportion of our subjects to have thalassaemic indices not associated with raised $\mathrm{HbA}_{2}$, and three such cases did appear in our Black control group compared with only one Indian and one Oriental.

Analysis of dietary information showed that red meat was the principle source of protein in the diets of Blacks and Orientals. This was especially true of the Blacks whose nutritional status was reflected in their $\%$ IBW. In contrast, $22 \%$ of our Indians were vegetarians. Vegetarianism is not necessarily associated with anaemia, except in the inadequately nourished, and we did not find a greater number of anaemic individuals among our Indian vegetarians although they did show a lower median, $\mathrm{Hb}$ and MCV.

The analysis of indices of iron status provides strong evidence for a high incidence of iron deficiency in our Indian group. Nutritional iron deficiency is the cause of $90 \%$ of anaemia on the Indian subcontinent, ${ }^{24}$ and this is also associated with folate deficiency in $30-50 \%$ of subjects. A high incidence of nutritional anaemia is generally believed to extend to Indians as immigrants to the United Kingdom. ${ }^{1011}$ Our Indian group showed lowest median ferritin, iron and transferrin saturation, and highest TIBC, and also the greatest proportion of individuals with low ferritin, iron and transferrin saturation levels. The White group gave median ferritin and iron levels lower than those of the Black and Oriental groups, although it showed the lowest proportion of individuals with ferritin levels of less than $12.0 \mathrm{ng} / \mathrm{l}$. The low haemoglobin concentrations found in the Black population were not reflected in the indicators of iron status used in this study, and the relatively high median ferritin concentrations in Black and Oriental populations, thus appear to reflect a greater number of individuals with comparatively high ferritin concentrations in these groups, rather than iron deficiency in the White groups, in which there were no individuals with $\mathrm{Hb}$ less than $11 \cdot 2 \mathrm{~g} / \mathrm{dl}$.

Our analysis of the iron status of our Indian population provides strong evidence for a nutritional basis for the low haemoglobin levels observed in this group. Reduced absorption or low intake of iron, or both, would be factors involved in this. Calcium, phosphate, and alkaline phosphatase levels did not indicate any interference with iron absorption by dietary chelating agents such as phytates. If low iron intake were the primary cause of anaemia in the Indian group, then iron supplementation would be expected to have a beneficial effect on haematological indices. This was found to be the case in a subsequent study in which 11 Indians were given oral iron over a period of two months. Serum iron, 
TIBC, $\mathrm{Hb}$, and MCV were measured before and after iron supplementation. Although median levels of these parameters before treatment did not fall outside the normal range, there was nevertheless a highly significant rise in both serum iron and transferrin saturation and significant increases in $\mathrm{Hb}$ and MCV after treatment.

The theory of reference values requires that reference individuals in a population should be comparable in a number of defined variables. ${ }^{30}$ It would appear from this study, that our group of Indian subjects were not comparable in iron and nutritional status with our White reference population. Diagnosis of anaemia in an Indian population can be effectively based on White reference values, though unequivocal diagnosis must await a reference value derived from an Indian group with adequate iron nutrition.

Our study indicates that reference values based upon White populations are applicable to the Orientals in our community, in whom adequate nutrition, iron status and iron stores, as estimated by ferritin levels, were associated with an incidence of low $\mathrm{Hb}$ concentrations similar to that in the normal White female population.

The low $\mathrm{Hb}$ concentration in our Black population is evidently not primarily due to nutritional factors, as indicated by dietary history and iron status. The possibility remains that there may be a prevalent but not easily detectable genetic impairment of haemoglobin synthesis in our Black population. However, a clear understanding of the contribution that the alpha-thalassaemias could make to these low $\mathrm{Hb}$ concentrations must await a thorough survey based on haemoglobin chain synthesis studies.

The haematological differences we have observed between Black and White populations agree with the findings of a number of workers in the USA where separate reference values for Black haematological indices are currently under discussion. On the strength of our findings, these may be equally applicable to the Black population in the UK.

We thank Dr Barbara Bain, Consultant Haematologist, St Mary's Hospital Medical School for her invaluable advice and assistance throughout the preparation of this paper.

We would also like to thank Dr Helen Dodsworth, Consultant Haematologist and Dr M Davie, Lecturer in Human Metabolism for their help and suggestions and staff nurses Barbara Walker and Anne Langford for their assistance in taking samples in the Metabolic Day Ward.

We also thank Miss Stephanie Dodridge, Mrs Vienne Worlock and Miss Audrey Gibbons for secretarial assistance.
This work was carried out with the aid of generous grants from the Overseas Development Administration and the Jules Thorn Trust.

\section{References}

' Ten State Nutrition Survey. US Department of Health, Education and Welfare. DHEW Publ No (HSM) 72-8130. Washington DC, 1972.

${ }^{2}$ Garn SM, Smith NJ, Clarke DC. Lifelong differences in haemoglobin levels between Blacks and Whites. $J$ Nat Med Assoc 1975;67:91-6.

${ }^{3}$ Abraham SE, Lowenstein W, Johnson CL. Preliminary findings of the First Health and Nutrition Examination Survey, United States, 1971-1972: dietary intake and biochemical findings. DHEW Publ No (HRA) 74-1219. Washington DC, 1974.

${ }^{4}$ Koh ET, Chi MS, Lowenstein FW. Comparison of selected blood components by race sex and age. Am J Clin Nutr 1980;33:182835 .

5 Williams DM. Racial differences of haemoglobin concentration: measurement of iron, copper and zinc. Am J Clin Nutr 1981;34:1694-700.

- Dallman PR, Barr GD, Allen CM, Shinefield HR. Haemoglobin concentration in White, Black and Oriental children: is there a need for separate criteria in screening for anaemia? Am J Clin Nutr 1978;31:377-80.

' Pierce HI, Kurachi S, Sofroniadou K, Stamatoyannopouos G. Frequencies of thalassaemia in American Blacks. Blood 1977;49:981-6.

${ }^{8}$ Dozy AM, Yan YW, Embury SH, et al. Alpha globin gene organisation in Blacks precludes the severe form of alphathalassaemia. Nature 1979;280:605-7.

9 Pornpatkul M, Wasi P, Na-Nakorn S. Haematologic parameters in obligatory alpha-thalassaemia. J Med Assoc Thai 1969;52:8019.

${ }^{10}$ Elwood PC, Burr ML, Hole D, et al. Nutritional state of elderly Asian and English subjects in Coventry. Lancet 1972;i:1224-7.

" Roberts PD, James H, Petrie A, Morgan JO, Hoffbrand AV. Vitamin $B_{12}$ status in pregnancy among immigrants to Britain. Br Med J 1973;iii:67-72.

${ }^{12}$ Burton JL. Effects of oral contraceptives on haemoglobin, packed cell volume, serum iron and total iron binding capacity in healthy women. Lancet 1967;i:978-80.

${ }^{13}$ Callard GV, Litofsky FS, De Merre LJ. Menstruation in women with normal or artificially controlled cycles. Fertil Steril 1966;17:684-8.

${ }^{14}$ Paton A. Oral contraceptives and folate deficiency. Lancet 윽 1969;i:418.

${ }^{15}$ Fawcett JK, Wynn V. Effects of posture on plasma volume and some blood constituents. J Clin Pathol 1960;13:304-10.

${ }^{16}$ Diem K, ed. Documenta Geigy. 6th ed. Manchester, 1962:623.

" Garn SM, Ryan AS, Abraham S, Owen G. Suggested sex and age appropriate values for "low" and "deficient" haemoglobin levels. Am J Clin Nutr 1981;34:1648-51.

${ }^{18}$ Lipschitz DA, Cook JD, Finch CA. A clinical evaluation of serum ferritin as an index of iron stores. N Engl J Med 1974;290:1213 6.

19 Weippl G, Pantlitschko M, Bauer P, Lund S. Serumeisen, Normalwerte und statistische Verteilung der Einzelwerte bei $\mathscr{\mathcal { S }}$ Mann and Frau. Blut 1973;27:261-70.

${ }^{20}$ Garn SM, Ryan AS, Owen GM, Abraham S. Income matched black-white haemoglobin differences after correction for low transferrin saturations. Am J Clin Nutr 1981;34:1645-7.

${ }^{21}$ Prema K. Haemoglobin levels in contraceptive users. Ind J Med Res 1979;69:756-60.

${ }^{22}$ Chalmers DM, Levi AJ, Chanarin I, North WRS, Meade TW. Mean cell volume in a working population: the effects of age, 
smoking, alcohol and oral contraception. Br J Haematol 1979;43:631-6.

2.3 Dodsworth H, Dean A, Broom G. Effects of smoking and the pill on the blood count. Br J Haematol 1981;41:484-8.

${ }^{24}$ Krishna Das KV. Nutritional anaemias in India. $J$ Assoc Physicians India 1980;28:521-33.

${ }^{25}$ Rippey JJ. Leucopenia in West Indians and Africans. Lancet 1967;ii:44.

${ }^{26}$ Choulham DM, Sharma RS, Parekh JG. Alpha-thalassaemia in India. J Ind Med Assoc 1970;54:364-7.

${ }^{27} \mathrm{Na}-\mathrm{Nak}$ orn $\mathrm{S}$, Wasi P. Alpha-thalassaemia in Northern Thailand. Am J Hum Genet 1970;22:645-51.
${ }^{28}$ Weatherall DJ, Clegg JB. The thalassaemia syndrome. 3rd ed. Oxford: Blackwell Scientific Publications; 1981:303.

${ }^{29}$ Walford DM, Deacon R. Alpha-thalassaemia trait in various racial groups in the United Kingdom: characterisation of a variant of alpha-thalassaemia in Indians. Br J Haematol 1976;34:193-206.

${ }^{30}$ International Committee of Standardisation in Haematology. The theory of reference values. Clin Lab Haematol 1981;3:369-73.

Requests for reprints to: Mr IF Godsland, Alexander Simpson Laboratory for Metabolic Research, St Mary's Hospital Medical School, London W2, England. 